\title{
LONG-TERM IMMUNITY ALTERATIONS IN THE EMPLOYEES OF THE HIGH HYDROGEN SULFIDE CONTENT GAS CONDENSATE PROCESSING FACILITY
}

Boiko OV凶, Dotsenko Yul

Astrakhan State Medical University, Astrakhan, Russia

The current measures for protection of the gas processing plant employees cannot fully prevent the impact of pollutants. Evaluation of the immune system is one of the methods for monitoring of the employees' health, and testing the system of measures used to improve the working conditions. The study was aimed to identify alterations in the immune status of the employees at the gas processing and high hydrogen sulfide content condensate processing facility depending on their working experience. The working environment and the employees' immune system were evaluated by standard methods. Pollutants were detected with the Bruel \& Kjaer 1302 Multi-Gas Monitor, and the Tsvet-550 gas chromatographer. A total of 160 employees and 81 controls (blood donors of the regional blood transfusion station) were surveyed. The immune system was evaluated using the System 9000 Plus hematological analyser, Cyto FLEX LX flow cytometer, UNICO 2100 UV specrophotometer, and KFK-3-03-ZOM3 photometer. It was concluded that the existing complex of occupational and industrial hazards affects the immune status of the main production unit employees, which is reflected in the decreased CD20 levels and increased CD8 levels along with the constant levels of CD4. Correlations were revealed between the immuniglobuline level alterations, decrease in the phagocytic index and phagocytic number, as well in lysozyme activity, and the working experience. Pollutant exposure results in altered immunity of the employees, which could be considered the adaptation mechanism.

Keywords: production factors, pollutants, immunological indicators

Author contribution: Boiko OV — study concept and design, data acquisition and processing; Dotsenko Yul — data acquisition and processing; all the authors — approval of the final version of the article, responsibility for integrity of all article sections.

Compliance with ethical standards: the study was approved by the Ethics Commitee of the municipal outpatient clinic № 8 (protocol № 15 dated №vember 21 , 2020); the informed consent was submitted by all study participants.

$\triangle$ Correspondence should be addressed: Oksana V. Boiko

Bakinskaya, 121, 414000, Astrakhan, Russia; oboyko08@mail.ru

Received: 30.11.2021 Accepted: 13.12.2021 Published online: 18.12.2021

DOI: $10.47183 /$ mes.2021.041

\section{СТАЖЕВЫЕ ИЗМЕНЕНИЯ ИММУНИТЕТА РАБОЧИХ ПРЕДПРИЯТИЯ ПО ПЕРЕРАБОТКЕ ГАЗОКОНДЕНСАТА С ВЫСОКИМ СОДЕРЖАНИЕМ СЕРОВОДОРОДА}

\author{
О. В. Бойко , Ю. И. Доценко
}

Астраханский государственный медицинский университет, Астрахань, Россия

\begin{abstract}
Существующие меры защиты сотрудников газоперерабатывающих заводов не могут полностью предотвратить воздействие на них поллютантов. Одним из методов мониторинга здоровья рабочих и системы мероприятий по нормализации условий труда является исследование иммунной системы. Целью работы было выявить изменения в иммунном статусе рабочих, занятых на предприятии по переработке газа и конденсата с высоким содержанием сероводорода в зависимости от их стажа. Использовали стандартные методы для характеристики производственной среды и оценки состояния иммунной системы работающих. Для индикации поллютантов применяли универсальный газовый монитор 1302 Bruel \& Kjaer, газовый хроматограф Цвет550. Были обследованы 160 рабочих, а также 81 человек контрольной группы (доноры областной станции переливания крови). Исследования иммунной системы проводили на гематологическом анализаторе Sistem 9000 Plus, цитофлуориметре Cyto FLEX LX, спектрофотометре UNICO $2100 U V$, фотометре фотоэлектрическом КФК-З-0З-ЗОМЗ. Сделаны выводы, что комплекс существующих профессионально-производственных вредностей оказывает влияние на состояние иммунитета рабочих основных производств, которое проявляется в снижении содержания CD20 и увеличении содержания CD8 при почти неизменном содержании CD4. Выявлена взаимосвязь изменения концентрации иммуноглобулинов, снижения фагоцитарного индекса и фагоцитарного числа, а также активности лизоцима с увеличением производственного стажа. Воздействие поллютантов вызывает изменения состояния иммунитета рабочих, что может быть расценено как приспособительный механизм.
\end{abstract}

Ключевые слова: производственные факторы, поллютанты, иммунологические показатели

Вклад авторов: О. В. Бойко - концепция и дизайн исследования, сбор и обработка материала, статистическая обработка, написание текста; Ю. И. Доценко - сбор и обработка материала; все соавторы - утверждение окончательного варианта статьи, ответственность за целостность всех частей статьи.

Соблюдение этических стандартов: исследование одобрено этическим комитетом Городской поликлиники № 8 (протокол № 15 от 21 ноября 2020 г.); все участники исследования подписали добровольное согласие на участие в исследовании.

$\bigotimes$ Для корреспонденции: Оксана Витальевна Бойко

ул. Бакинская, д. 121, 414000, г. Астрахань, Россия; оboyko08@mail.ru

Статья получена: 30.11.2021 Статья принята к печати: 13.12.2021 Опубликована онлайн: 18.12.2021

DOI: $10.47183 /$ mes.2021.041

Air pollution with harmful chemicals inside the gas processing plants remains the major hygiene factor that might have some influence on the employees' health [1-6]. Gas from the Astrakhan field, having the unique natural composition, has a certain impact both on the environment and the human body. It is distinguished by high hydrogen sulfide content (up to 25\%), along with hydrocarbons (2.84\%), carbon oxides (14-20\%), nitrogen oxides $(2.45 \%)$, mercaptans $(0.03-0.22 \%)$, and carbonyl sulphide (0.02-0.42\%) [3]. The current measures for protection of the gas processing plant employees cannot fully prevent the impact of harmful factors.

In this regard, there is a scientific and practical interest in the qualitative and quantitative assessment of the changing immunological parameters, which reflect the essence of the emloyee's body alteration and make it possible to monitor the employees' health in a timely manner in order to prevent 
the risk of developing a disease [7-8]. Immune system is one of the body systems, being the most responsive to pollutant exposure; immunological tests may be regarded as the most reliable tests for establishing the causal relationship between the disease and the hazardous working conditions. However, there are just a few papers on this issue [8-11]. The data on the immune system sensitivity to the long-term exposure to production factors is also insufficiently represented in literature [9-16].

\section{METHODS}

The workplace hygiene certification involved assessing the concentrations of air pollutants in the working area based on legislative requirements.

Determination of $\mathrm{SO}_{2}$ in air was performed using the Bruel \& Kjaer 1302 Multi-Gas Monitor (Bruel \& Kjaer; Denmark). The H2S concentrations were assessed by photometric method based on the interaction of hydrogen sulfide with sodium arsenite and silver nitrate. Alkanes (C1-C10), alkenes (C2-C5), and aromatic hydrocarbons (benzene, toluene, xylenes and ethylbenzene) were assessed by gas chromatography. These substances were detected using the Tsvet-550 gas chromatographer (Rospribor; Russia). Along with the listed above methods, hydrocarbons (total) were assessed with the Bruel \& Kjaer 1302 Multi-Gas Monitor. The concentration of nitrogen oxides was measured by photometry. Determination of methanol in air in the working areas was performed by gas chromatography, and carbon monoxide was assessed by the reaction gas chromatography. The Bruel \& Kjaer 1302 MultiGas Monitor was also used for this purpose.

A total of 160 employees (operators, engine drivers) of the main and auxiliary facilities of the gas processing plant were surveyed. Inclusion criteria: males; age 30-40 years (the average age was 36.4 years). A total of 81 controls (blood donors of the regional blood transfusion station) were also surveyed. The control group inclusion criteria were as follows: individuals matching the facility employees in gender and age (comparing the groups by age revealed no significant differences ( $p$ > 0.05)); exclusion criteria: professional experience in the gas processing, petroleum or chemical industry; exposure to any chemical process hazard.

The studied group was surveyed during the routine medical examination with the use of the standard assessment methods. All the participants were divided into groups based on their length of service with the plant: $1-3$ years, 3-5 years, 5-10 years, 10 years or more.

Hematological tests were performed using the System 9000 Plus automatic hematological analyser (Serono; Switzerland). Samples were analyzed with the Cyto FLEX LX flow cytometer (Beckman Coulter; USA) in order to determine the lymphocyte subpopulations. Phagocytic cells were examined by the direct morphological method. Classes of immunoglobulins were determined by a turbidimetric assay; concentrations of the circulating immune complexes $(\mathrm{CIC})$ were defined by precipitation with polyethylene glycol (PEG-6000) and registered at $280 \mathrm{~nm}$ with the UNICO $2100 \mathrm{UV}$ spectrophotometer (United Products \& Instruments, Inc.; USA). Lysozyme activity was detected by turbidity assay based on measuring the changes in the turbidity of the Micrococcus lysodeikticus suspension with the KFK-3-03-ZOM3 photometer (Zagorsk Optical-Mechanical Plant; Russia).

Statistical analysis of the results was performed using the Statistica 12 software (StatSoft; USA) and the analysis of variance. Previously the descriptive statistics data were assessed: number of observations that constituted the sample $(n)$, arithmetic mean of the data obtained (M), standard deviation $(m)$, standard error of the mean $(T)$, minimum (min) and maximum (max) values of the studied parameter, as well as the relative values (\%) and the corresponding errors. The quantitative data distribution was assessed using the ShapiroWilk test. In case of compliance with the normal distribution law, the method of statistical analysis was selected (parametric or nonparametric). When the quantitative variables were distributed normally, central tendencies and dispersion were described using mean values (M) and standard deviations $(m)$. Significance of the differences was defined with the use of the Wilcoxon test and the Mann-Whitney $U$ test; the differences were considered significant when $p<0.05$.

\section{RESULTS}

The findings demonstrate the presence of significant air concentrations of numerous harmful substances in the working area. Despite the fact that almost all of these substances are involved in the technological processes and are almost completely converted to sulfur compounds (patricularly, to sulfur dioxide) or removed through the chimneys of the facility (carbon oxides), the constant presence of pollutants in the working area is observed. The presence of those is characteristic not only of the purely production areas (pump rooms, engine rooms), but also of the soundproof compartments with no production machinery installed (Table 1).

The impact of production factors on the employees' health is confirmed by the correlation between the detected changes in immune status and the working experience. It was found that with an increase in the working experience, there were trends towards the increase in white blood cell and lymphocyte counts, decrease in the levels of CD20, and progressive increase in the levels of CD8 along with the constant levels of CD4 (Table 2).

Correlations between the alterations of the cellular and humoral factors and the employees' working experience. The indicators of phagocytosis were characterized by progressive decrease in the phagocytic index and phagocytic number with the increase in the working experience, which was to some extent offset by the increase in the total number of phagocytic cells. However, such a compensatory capacity started to decline in individuals with working experience exceeding 10 years.

The humoral factors of nonspecific resistance demonstrate a greater diversity of the correlations with working experience. Thus, lysozyme activity in employees progressively decreases with the increase in their working experience, and the classes of immunoglobulins show a variety of responses. The trend towards the decrease in concentrations is characteristic of lgG, and the trend towards the increase is characteristic of IgA and IgM.

Thus, the correlation between the changes in the majority of the immune status indicators and the employees' working experience and, therefore, their working conditions, has been shown, which confirms the professional etiology of these alterations. However, the changes are phase-type, which makes it possible to treat the alterations as different stages of the adaptation process.

To identify the possible correlations between the serum and saliva levels of certain humoral resistance factors, we assessed lysozyme activity in the saliva obtained from different groups of employees. It was found that the changes of this indicator in blood and saliva of the employees were almost exactly the same both in terms of tendencies and intensity. Moreover, the discovered similarities have been found in all groups of employees, which makes it possible to use lysozyme levels for 
Table 1. Concentrations of harmful substances in the air of the working areas

\begin{tabular}{|c|c|c|c|c|c|c|}
\hline \multirow{2}{*}{ Air sampling site } & \multirow{2}{*}{ Pollutants } & \multirow{2}{*}{ Number of tests } & \multicolumn{3}{|c|}{ Pollutant concentrations, $\mathrm{mg} / \mathrm{m}^{3}$} & \multirow{2}{*}{$\mathrm{MPC}, \mathrm{mg} / \mathrm{m}^{3}$} \\
\hline & & & $\min$ & $\max$ & mean $\mathrm{M} \pm m$ & \\
\hline \multirow{6}{*}{ Engine rooms } & Hydrogen sulfide & 25 & 1.3 & 8.1 & $5.4 \pm 0.8$ & 3.0 \\
\hline & Sulphur dioxide & 25 & 1.3 & 45.3 & $23.1 \pm 2.6$ & 10.0 \\
\hline & Nitrogen dioxide & 22 & 0.9 & 4.1 & $2.1 \pm 0.3$ & 2.0 \\
\hline & Carbon monoxide & 16 & 3.9 & 53.1 & $29.1 \pm 6.0$ & 20.0 \\
\hline & Hydrocarbons & 25 & 1.5 & 80.0 & $43.1 \pm 4.6$ & 300.0 \\
\hline & Mercaptans & 15 & 0.3 & 2.2 & $1.24 \pm 0.2$ & 0.8 \\
\hline \multirow{6}{*}{ Pump rooms } & Hydrogen sulfide & 25 & 1.1 & 7.7 & $5.1 \pm 0.8$ & 3.0 \\
\hline & Sulphur dioxide & 25 & 2.5 & 54.6 & $27.4 \pm 4.5$ & 10.0 \\
\hline & Nitrogen oxides & 22 & 1.4 & 3.7 & $3.0 \pm 0.6$ & 2.0 \\
\hline & Carbon monoxide & 16 & 3.2 & 49.7 & $25.1 \pm 5.6$ & 20.0 \\
\hline & Hydrocarbons & 25 & 2.7 & 63.8 & $38.3 \pm 3.9$ & 300.0 \\
\hline & Mercaptans & 15 & 0.2 & 2.1 & $1.07 \pm 0.25$ & 0.8 \\
\hline \multirow{6}{*}{$\begin{array}{l}\text { Soundproof compartments in engine } \\
\text { rooms }\end{array}$} & Hydrogen sulfide & 23 & 1.0 & 7.4 & $5.0 \pm 0.7$ & 3.0 \\
\hline & Sulphur dioxide & 25 & 0.6 & 32.2 & $12.6 \pm 3.4$ & 10.0 \\
\hline & Nitrogen dioxide & 22 & 1.7 & 3.8 & $3.01 \pm 0.09$ & 2.0 \\
\hline & Carbon monoxide & 16 & 3.6 & 49.4 & $25.3 \pm 6.0$ & 20.0 \\
\hline & Hydrocarbons & 25 & 1.8 & 72.8 & $30.6 \pm 2.6$ & 300.0 \\
\hline & Mercaptans & 15 & 0.2 & 2.0 & $1.7 \pm 0.3$ & 0.8 \\
\hline \multirow{6}{*}{$\begin{array}{l}\text { Soundproof compartments in pump } \\
\text { rooms }\end{array}$} & Hydrogen sulfide & 23 & 1.0 & 6.2 & $4.8 \pm 0.6$ & 3.0 \\
\hline & Sulphur dioxide & 25 & 3.3 & 31.4 & $14.3 \pm 5.9$ & 10.0 \\
\hline & Nitrogen oxides & 22 & 1.3 & 3.0 & $1.9 \pm 0.2$ & 2.0 \\
\hline & Carbon monoxide & 16 & 3.1 & 41.6 & $24.3 \pm 5.9$ & 20.0 \\
\hline & Hydrocarbons & 25 & 18.2 & 88.6 & $45.2 \pm 9.2$ & 300.0 \\
\hline & Mercaptans & 15 & 0.2 & 1.4 & $0.7 \pm 0.21$ & 0.8 \\
\hline \multirow{6}{*}{ Compressor house } & Hydrogen sulfide & 24 & 0.6 & 1.8 & $1.1 \pm 0.2$ & 3.0 \\
\hline & Sulphur dioxide & 24 & 3.8 & 22.6 & $16.6 \pm 2.4$ & 10.0 \\
\hline & Nitrogen oxides & 23 & 0.8 & 3.8 & $2.2 \pm 0.2$ & 2.0 \\
\hline & Carbon monoxide & 15 & 3.3 & 33.3 & $17.2 \pm 1.6$ & 20.0 \\
\hline & Hydrocarbons & 25 & 3.0 & 38.6 & $23.2 \pm 5.8$ & 300.0 \\
\hline & Mercaptans & 14 & 0.2 & 1.4 & $0.8 \pm 0.31$ & 0.8 \\
\hline \multirow{6}{*}{$\begin{array}{l}\text { Rack for manual loading of sulfur } \\
\text { and trucking area for solid and } \\
\text { granulated sulfur }\end{array}$} & Hydrogen sulfide & 50 & 1.3 & 66.5 & $29.8 \pm 6.8$ & 3.0 \\
\hline & Sulphur dioxide & 53 & 7.4 & 360.0 & $57.2 \pm 9.6$ & 10.0 \\
\hline & Nitrogen oxides & 28 & 0.6 & 3.4 & $1.8 \pm 0.2$ & 2.0 \\
\hline & Carbon monoxide & 62 & 3.8 & 47.5 & $22.9 \pm 5.1$ & 20.0 \\
\hline & Hydrocarbons & 54 & 1.7 & 12.2 & $7.9 \pm 0.9$ & 300.0 \\
\hline & Sulphur dust & 42 & 8.4 & 21.4 & $13.7 \pm 1.4$ & 6.0 \\
\hline
\end{tabular}

noninvasive diagnosis. Serum lysozyme levels in employees reached $5.43 \pm 0.29 \mu \mathrm{g} / \mathrm{mL}$, and serum lysozyme levels in controls were $6.48 \pm 1.42 \mu \mathrm{g} / \mathrm{mL}$. Saliva lysozyme levels in employees were $8.82 \pm 0.49 \mu \mathrm{g} / \mathrm{mL}$, and in controls these were $10.41 \pm 0.65 \mu \mathrm{g} / \mathrm{mL}$.

\section{DISCUSSION}

Research has shown that the complex of occupational and industrial hazards specific to the enterprises that process gas condensate with high hydrogen sulfide content has a certain impact on the immune system of the employees. The accompanying bodily processes are directly related to the duration of exposure to the production factors, i.e. depend on the working experience in the gas industry.

The decrease in the phagocytic activity of peripheral blood neutrophils we have identified is very much in line with the existing literature data, and can be interpreted as a consequence of the employees' intoxication with air pollutants present in the factory premises. The groundwork is thus being laid for inefficient elimination of the infectious causative agents, and, consequently, for chronic infections, to the extent of becoming the resident bacteria carrier. This assumption could be supported by the elevated levels of $\lg A$ found in the factory employees. It is known that it is $\lg A$ which is responsible for the mucous membrane resistance to pathogens, and the IgA concentration increase is associated with inflammation in the area of the entrance gate of infection. Taking into account the decrease in lysozyme activity observed both in blood serum and saliva of the employees compared to controls, there is a theoretical possibility of the chronic infectious disease.

The long-term persistence of an infectious agent in the human body may, among other things, result in the autoimmune disorder development. An example is the autoantibody against the TSH receptor gangliosid region, which is responsible for 
Table 2. Immune status indicators in employees of the Astrakhan Gas Processing Plant with different working experience

\begin{tabular}{|c|c|c|c|c|c|}
\hline \multirow{2}{*}{ Indicators } & \multicolumn{5}{|c|}{ Mean values by groups, $\mathrm{M} \pm m$} \\
\hline & Group 1 & Group 2 & Group 3 & Group 4 & Control group \\
\hline White blood cells, $\times 10^{9}$ & $7.35 \pm 0.37$ & $7.88 \pm 0.33$ & $8.35 \pm 0.26^{\star *}$ & $7.35 \pm 0.32$ & $5.27 \pm 0.36$ \\
\hline Lymphocytes, \% & $36.8 \pm 1.87$ & $37.2 \pm 0.83$ & $38.9 \pm 1.46$ & $38.3 \pm 1.42$ & $34.23 \pm 1.88$ \\
\hline CD3, \% & $56.6 \pm 1.54$ & $58.0 \pm 1.76$ & $57.5 \pm 1.76$ & $57.3 \pm 1.6$ & $56.38 \pm 2.12$ \\
\hline CD4, \% & $36.1 \pm 1.31$ & $36.1 \pm 1.49$ & $38.0 \pm 0.67$ & $38.7 \pm 1.6$ & $38.69 \pm 1.98$ \\
\hline CD8, \% & $19.5 \pm 0.73$ & $20.5 \pm 1.37$ & $21.9 \pm 1.35$ & $18.6 \pm 1.8$ & $17.69 \pm 0.88$ \\
\hline CD4/CD8 & $2.32 \pm 0.12$ & $2.06 \pm 0.19$ & $1.83 \pm 0.15^{\star \star}$ & $2.42 \pm 0.3$ & $2.25 \pm 0.17$ \\
\hline CD20, \% & $14.7 \pm 0.72$ & $13.9 \pm 0.38$ & $13.5 \pm 0.69$ & $14.2 \pm 0.6$ & $14.64 \pm 0.85$ \\
\hline $\operatorname{lgG}, g / L$ & $9.21 \pm 0.12$ & $9.04 \pm 0.19$ & $9.03 \pm 0.2$ & $9.11 \pm 0.2$ & $9.45 \pm 0.33$ \\
\hline $\lg A, g / L$ & $1.81 \pm 0.07$ & $1.84 \pm 0.08$ & $1.84 \pm 0.04$ & $1.86 \pm 0.06$ & $1.87 \pm 0.08$ \\
\hline $\operatorname{lgM}, \mathrm{g} / \mathrm{L}$ & $1.24 \pm 0.07$ & $1.28 \pm 0.06$ & $1.28 \pm 0.04$ & $1.29 \pm 0.07$ & $1.33 \pm 0.11$ \\
\hline $\mathrm{CIC}, \mathrm{AU}$ & $4.77 \pm 0.41$ & $5.01 \pm 0.44$ & $5.83 \pm 0.27$ & $5.45 \pm 0.47$ & $2.49 \pm 0.5$ \\
\hline Phagocytic index, \% & $72.1 \pm 2.51$ & $70.7 \pm 0.75^{\star}$ & $66.4 \pm 0.16^{* *}$ & $67.1 \pm 3.0$ & $73.64 \pm 2.3$ \\
\hline Phagocytic number, & $5.73 \pm 0.27$ & $5.65 \pm 0.2^{\star}$ & $5.08 \pm 0.11^{\star \star}$ & $5.36 \pm 0.32$ & $6.98 \pm 0.39$ \\
\hline Phagocytic activity per $1 \mu \mathrm{L}$ & $3033 \pm 239$ & $2961 \pm 231$ & $3183 \pm 143$ & $2609 \pm 202$ & $2345 \pm 232$ \\
\hline Lysozyme, $\mu \mathrm{g} / \mathrm{mL}$ & $5.67 \pm 0.48$ & $4.86 \pm 0.64$ & $4.17 \pm 0.54^{\star \star}$ & $6.16 \pm 1.29$ & $6.48 \pm 1.42$ \\
\hline
\end{tabular}

Note. * - significant differences $(p<0.05)$ between groups 2 and 3 ; ${ }^{* *}$ — significant differences $(p<0.05)$ between groups 1 and 3 ; group 1 - working experience 1-3 years, group 2 - working experience 3-5 years, group 3 - working experience 5-10 years, group 4 - working experience exceeding 10 years.

the development of hyperthyroidism associated with Graves' disease. Certain bacterial infections trigger the development of such autoimmune disorders, since glycosphingolipids of bacterial antigens often cause cross-reactivity. In Graves' disease, this role is played by Yersinia enterocolitica.

Considering the fact that $\lg \mathrm{M}$ is capable of complement activation and playing a part of the mediator in the cytotoxic reactions, that we and other researchers define as the increased IgM levels in the employees of the chemical production facilities, IgM is capable of facilitating the employees' predisposition to autoimmune disorders.

\section{CONCLUSIONS}

Maximum consumption of raw material and all intermediate products used in the the natural sulfur containing gas and condensate processing, achieved by highly efficient operation of the major production objects (Claus process and Sulfreen), is of primary importance in terms of improving working conditions in the studied industries. This would make it possible to minimize the overall air pollution and the pollution of air specifically inside the premises of the Astrakhan Gas Processing Plant. High level of sealing for the technological equipment, installed in the engine room (pumps, compressors, valves), is required, as well as organization of automated control of the components in the flow. Both direct and indirect impact of the Astrakhan Gas Processing Plant prodiction factors causes the noticeable changes in the immune status of the employees, which could be considered the adaptation mechanism. The identified changes in the immune status could be one of the factors, contributing to the rising morbidity rate in the facility employees, being the most susceptible to the damaging effects of specific factors of the working environment. This suggests that it is appropriate to include immunological tests in the routine hygienic assessment of the working conditions at the gas production facilities. Taking into account the strength of the used laboratory methods, these methods can be recommended for the inclusive health check-ups of employees. The results obtained may be used as criteria for distinguishing the risk groups for rehabilitation, as well as for occupational selection of new personnel.

\section{References}

1. Lawson SM, Masterson EA, Azman AS. Prevalence of hearing loss among noise-exposed workers within the Mining and Oil and Gas Extraction sectors, 2006-2015. Am J Ind Med. 2019; 62 (10): 826-37. DOI: 10.1002/ajim.23031.

2. Boiko OV, Akhmineeva AKh, Boiko VI, Gudinskaya NI. Influence of Astrakhan gas processing plant on the air pollution by harmful chemical substances of industrial premises and the territory. Hygiene and Sanitation. 2016. 95 (2): 167-71. DOI: 10.18821/0016-9900-2016-95-2-167-171. Russian.

3. Notley SR, Flouris AD, Kenny GP. Occupational heat stress management: Does one size fit all? Am J Ind Med. 2019; 62 (12): 1017-23. DOI: 10.1002/ajim.22961.

4. Heinzerling A, Laws RL, Frederick M, Jackson R, Windham G, Materna B, et al. Risk factors for occupational heat-related illness among California workers, 2000-2017. Am J Ind Med. 2020; 63 (12): 1145-54. DOI: 10.1002/ajim.23191.

5. Binazzi A, Levi M, Bonafede M, Bugani M, Messeri A, Morabito M et al. Evaluation of the impact of heat stress on the occurrence of occupational injuries: Meta-analysis of observational studies. Am J Ind Med. 2019; 62 (3): 233-43. DOI: 10.1002/ajim.22946.

6. Valeev TK, Rakhmanin YuA, Suleymanov RA, Malysheva AG, Gimranova GG, Rakhmatullin NR, et al. Characteristics of the risk to the health of the population of the oil-producing region associated with environmental factors. Hygiene and Sanitation. 2021; 100 (11): 1310-6. Available from: https://doi. org/10.47470/0016-9900-2021-100-11-1310-1316. Russian.

7. Uyba W, Laver BI, Kulyga VN. Industrial medicine: its role and development prospects in the FMBA system of Russia. Meditsina ekstremal'nykh situatsiy (Medicine of Extreme Situations, Russian journal) 2019; 21 (2): 261-7. Russian.

8. Nazarova EL, Timofeeva VYu, Plehov VL, Shardakov VI, Kovtunova MYe, Minaeva NV, Rylov AV, Paramonov IV. Immunoreactivity status in workers at chemical industry plant - donors of plasma for fractionation. Meditsina ekstremal'nykh situatsiy. 2019; 21 (3): 
351-6. Russian.

9. Alikina IN, Dolgikh OV. Immunological status in employees of the mining and processing enterprise and chemical risk factors. Hygiene and Sanitation. 2021;100 (5): 471-5. Available from: https://doi.org/10.47470/0016-9900-2021-100-5-471-475 Russian.

10. Kryuchkova EN, Antoshina LI, Sukhova AV, Preobrazhenskaya EA. Influence of factors of electroplating production on the immunoreactivity of the body of workers. Hygiene and Sanitation. 2021; 100 (9): 959-63. Available from: https://doi. org/10.47470/0016-9900-2021-100-9-959-963. Russian.

11. Zemlyanova MA, Peskova EV, Koldibekova JV, Pustovalova OV. Study of changes in biochemical indices in workers employed in underground mining of chrome ore. Hygiene and Sanitation. 2021; 100 (10): 1103-8. Available from: https://doi.org/10.47470/00169900-2021-100-10-1103-1108. Russian.

12. Gaoyi Yao, Yang Yun, Nan Sang. Differential effects between one week and four weeks exposure to same mass of $\mathrm{SO} 2$ on synaptic plasticity in rat hippocampus. Environmental Toxicology. 2016; 31

\section{Литература}

1. Lawson SM, Masterson EA, Azman AS. Prevalence of hearing loss among noise-exposed workers within the Mining and Oil and Gas Extraction sectors, 2006-2015. Am J Ind Med. 2019; 62 (10): 826-37. DOI: 10.1002/ajim.23031.

2. Бойко О. В., Ахминеева А. Х., Бойко В. И., Гудинская Н. И. Влияние Астраханского газоперерабатывающего завода на загрязнение воздуха производственных помещений и территории. Гигиена и санитария. 2016. 95 (2): 167-71. DOI: 10.18821/0016-9900-2016-95-2-167-171.

3. Notley SR, Flouris AD, Kenny GP. Occupational heat stress management: Does one size fit all? Am J Ind Med. 2019; 62 (12): 1017-23. DOI: 10.1002/ajim.22961.

4. Heinzerling A, Laws RL, Frederick M, Jackson R, Windham G Materna B, et al. Risk factors for occupational heat-related illness among California workers, 2000-2017. Am J Ind Med. 2020; 63 (12): 1145-54. DOI: 10.1002/ajim.23191.

5. Binazzi A, Levi M, Bonafede M, Bugani M, Messeri A, Morabito M et al. Evaluation of the impact of heat stress on the occurrence of occupational injuries: Meta-analysis of observational studies. Am J Ind Med. 2019; 62 (3): 233-43. DOI: 10.1002/ajim.22946.

6. Валеев Т. К., Рахманин Ю. А., Сулейманов Р. А., Мальшева А. Г., Гимранова Г. Г., Рахматуллин Н. Р., Рахматуллина Л. Р., Бактыбаева З. Б. И др. Характеристика риска для здоровья населения нефтедобывающего региона в связи с факторами среды обитания. Гигиена и санитария. 2021; 100 (11): 1310-6. Доступно по ссылке: https://doi.org/10.47470/0016-99002021-100-11-1310-1316

7. Уйба В. В., Лавер Б. И., Кулыга В. Н. Промышленная медицина: ее роль и перспективы развития в системе ФМБА России. Медицина экстремальных ситуаций. 2019; 21 (2): 261-7.

8. Назарова Е. Л., Тимосееева В. Ю., Плехов В. Л., Шардаков В. И., Ковтунова М. Е., Минаева Н. В., и др. Состояние иммунореактивности у работников химических производств доноров плазмы для фракционирования. Медицина экстремальных ситуаций. 2019; 21 (3): 351-6.

9. Аликина И. Н., Долгих О. В. Иммунологический статус работников горно-перерабатывающего предприятия и
(7): 820-29. DOI: 10.1002/tox.22093.

13. Kåre Eriksson, Lage Burström, Tohr Nilsson. Blood biomarkers for vibration-induced white fingers. A case-comparison study. Am J Ind Med. 2020; 63 (9): 779-86. DOI: 10.1002/ajim.23148.

14. Boiko VI, Dotsenko Yul, Boiko OV. Acute phase proteins in the saliva of the workers at the plant for the processing of natural gas and condensate from the high content of hydrogen sulphide. Russian Clinical Laboratory Diagnostics. 2011; 6: 18-20. Russian.

15. Zemlyanova MA, Koldibekova JV, Peskova EV, Pustovalova OV, Ukhabov VM. Impact of the service terms on biochemical indices in employees at the potassium ore processing enterprise. Hygiene and Sanitation. 2021; 100 (5): 451-6. Available from: https://doi. org/10.47470/0016-9900-2021-100-5-451-456. Russian.

16. Zaitseva NV, Ulanova TS, Dolgikh OV, Nurislamova TV, Kazakova OA Maltseva OA. Immunological and genetic indices in workers under long-term exposure to low-doses of acrylonitrile. Hygiene and Sanitation. 2021;100(10):1115-1122. Available from: https://doi.org/10.47470/0016-9900-2021-100-10-1115-1122. Russian. химические факторы риска. Гигиена и санитария. 2021; 100 (5): 471-5. Доступно по ссылке: https://doi.org/10.47470/00169900-2021-100-5-471-475

10. Крючкова Е. Н., Антошина Л. И., Сухова А. В., Преображенская Е. А. Влияние факторов гальванического производства на иммунореактивность организма работающих. Гигиена и санитария. 2021;100 (9): 959-63. Доступно по ссылке: https:// doi.org/10.47470/0016-9900-2021-100-9-959-963.

11. Землянова М. А., Пескова Е. В., Кольдибекова Ю. В. Пустовалова О. В. Изменения биохимических показателей у работников, занятых подземной добычей хромовых руд. Гигиена и санитария. 2021; 100 (10): 1103-8. Доступно по ссылке:https://doi.org/10.47470/0016-9900-2021-100-101103-1108.

12. Gaoyi Yao, Yang Yun, Nan Sang. Differential effects between one week and four weeks exposure to same mass of SO2 on synaptic plasticity in rat hippocampus. Environmental Toxicology. 2016; 31 (7): 820-29. DOI: 10.1002/tox.22093.

13. Kåre Eriksson, Lage Burström, Tohr Nilsson. Blood biomarkers for vibration-induced white fingers. A case-comparison study. Am J Ind Med. 2020; 63 (9): 779-86. DOI: 10.1002/ajim.23148.

14. Бойко В. И., Доценко Ю. И., Бойко О. В. Остросазовые белки в слюне рабочих на предприятии по переработке природного газа и конденсата с высоким содержанием сероводорода. Клиническая лабораторная диагностика. 2011; 6: 18-20.

15. Землянова М. А., Кольдибекова Ю. В., Пескова Е. В. Пустовалова О. В., Ухабов В. М. Влияние длительности трудового стажа на биохимические показатели работников при переработке калиевой руды. Гигиена и санитария. 2021; 100 (5): 451-6. Доступно по ссылке: https://doi. org/10.47470/0016-9900-2021-100-5-451-456.

16. Зайцева Н. В., Уланова Т. С., Долгих О. В., Нурисламова Т. В., Казакова О. А., Мальцева О. А. Иммунологические и генетические показатели у работников при длительной низкоуровневой экспозиции акрилонитрилом. Гигиена и санитария. 2021; 100 (10): 1115-22. Доступно по ссылке: https://doi.org/10.47470/0016-9900-2021-100-10-1115-1122. 